\title{
VDAC1 Gene
}

National Cancer Institute

\section{Source}

National Cancer Institute. VDAC1 Gene. NCI Thesaurus. Code C37291.

This gene is involved in the regulation of small molecule transport through the outer mitochondrial membrane. 